УДК 94(497.1)"195/196"

323(497.1)"1966"

Milan PILJAK, M. A.

\title{
POWER GAME IN TITO'S YUGOSLAVIA: CONUNDRUM OF ALEKSANDAR RANKOVIĆ'S OVERTHROW FROM POWER*
}

\begin{abstract}
Article strives to explain the ousting of Aleksandar Ranković through rivalry within the League of Communists of Yugoslavia that originated from both Party and state crises. Reforms adopted in 1950s, made Yugoslavia more difficult to control from the federal level, since republican and other centers saw their opportunity in self-management to expand power on account of the federal government. Whole process is observed from the standpoint of a struggle for power within the LCY, and the state and question how much Yugoslavia needed to be centralized. Tito put in a tremendous effort to create an image that Rankovićs overthrow was in fact a continuum in Party's policy, neglecting the facts that they had been the closest associates till 1963. Rankovic was falsely accused for deviations of the Security apparatus in an attempt to take power by force. Hence, this article tries to reveal structural reasons for his downfall.
\end{abstract}

Key words: LCY unity, Party "rift", Aleksandar Ranković, Brioni plenum 1966

Quite a long time after the work of Branko Petranović ${ }^{1}$ in historiography, no serious efforts were made in presenting a different picture of the Brioni Plenum apart from the official Party allegations ${ }^{2}$ where the number two official, Aleksandar Ranković Marko ${ }^{3}$ was stripped of all his posts under the accusation

* This article has been written within the framework of the scholarly project Tradition and Transformation - Historical Heritage and National Identity in Serbia in 20 th Century (№ 47019), financed by the Ministry of Education, Science and Technological Development Republic of Serbia.

1 Branko Petranović, Istorija Jugoslavije, Vol III, Beograd: Nolit, 1988, str. 383-388.

2 Z. Radelić, Hrvatska u Jugoslaviji 1945-1991: od zajedništva do razlaza, Zagreb: Hrvatski inistitut za povijest i Školska knjiga, 2006, str. 360-366; D. Bilandžić, Hrvatska moderna povijest, Zagreb: Golden marketing, 1999, str. 489-504.

3 Aleksandar Ranković (1909-1983) was born in the village Draževac near Belgrade. He worked and trained to become tailor. In 1927 he joined YCLY (Young Communist League of Yugoslavia). He was twice arrested for illegal activities in the Kingdom of Yugoslavia. After the second arrest he served six years in prison, and after was promoted to the president of provincial committee of YCLY. He was arrested by the Gestapo on 27 June 1941, but was freed in a spectacular rescue action organized by the YCLY. During WWII he was one of the closest associates of Josip Broz. He was member of politburo 1940-1966 and organizational secretary of central committee of CPY/LCY 1942-1966. He was the head of party police OZNA 1944-1946, Minister of Interior 1946-1953, Vice President 1963-1966. R. Radošin, Jugoslovenski savremenici: Ko je ko u Jugoslaviji, Beograd: Hronometar, 1970, str. 885-886. From 1953-1963 he headed the Coordination Committee of Interior, thus controlling the whole state security apparatus. He was married twice. His first wife and brother were killed by Chetniks during WWII. His second wife was Slovenian, Ladislava. 
that he had wired the bedroom and bathroom of Josip Broz Tito, president of Yugoslavia and the head of the League of Communists of Yugoslavia (LCY) in order to overthrow Tito from power. ${ }^{4}$ Petranović was the first who stated in his work that the whole event was a décor to cover the real reasons for toppling the most powerful man after Josip Broz.

Attempts were made to explain Ranković's downfall but the majority of the various interpretations offered, only repeated the official accusations, making it clear that the authors had not read the available sources or taken advantage of the different details from the rich political life of Yugoslavia. ${ }^{5}$ The mist covering this topic could finally be cleared when the archives were opened and, documents and many memoirs became available in the late 1980s and 1990s. A new book written by a group of authors published new documents from the archives of the Security Organs within the State Secretariat of National Defence of Yugoslavia. ${ }^{6}$ These documents are of great importance since this is the first time they have been used, and this institution was the major instrument of Josip Broz in operationalising the removal of Aleksandar Ranković. These documents also confirmed that the removal of Ranković was done under false accusations. Having this knowledge we must seek to uncover the real or deeper reasons of this conundrum.

The most dominant concept used to explain the overall history of Yugoslavia and its breakdown has been the national question ${ }^{7}$ which tormented the Yugoslav state from its establishment in 1919. We will try to use a different approach in this article. Not because we think that the national question was of no great importance or that it was obsolete as a concept, but because we think that in the case of explaining the downfall of Aleksandar Ranković using this concept the explanation will be binary - Croats and Slovenians against Serbs. However we think that the ousting of Ranković was a climax of something far more complex and beyond the concept of clashed nationalities within Yugoslavia. Ethnic animosities existed but they, although troubling Yugoslavia were more or less successfully contained. We claim that the

4 The full official case was named: "Actual problems related to damaging activities of certain security organs and consequences of their activities upon both development of a system and activities of Central Committee". Archive of Yugoslavia, "League of Communists of Yugoslavia”, F. 507, IV (Brioni) Plenum 1966, VII 1, II/28, pp. 1-3.

5 For historiographical overview covering this topic, deconstructing various myths and reconstructing the whole event look for more details in: Милан Пиљак, “Брионски пленум 1966. године: покушај историографског тумачења догађаја”, Токови историје, 2010/1, Београд: Институт за новију историју Србије, 2010, стр. 73-95.

6 Светко Ковач, Бојан Димитријевић, Ирена Поповић Григоров, Случај Ранковић из архива KOC-a, Београд: Медија центар Одбрана, 2014.

7 Dennison Rusinow, The Yugoslav Experiment 1948-1974, London: C. Hurst \& Company, 1977, pp. 179-191; Sabrina P. Ramet, Nationalism and Federalism in Yugoslavia: 1962-1991, Bloomington IN: Indiana University Press, 1992; Sabrina P. Ramet, The Three Yugoslavias: State-Building and legitimation 1918-2005, Washington: Woodrow Wilson Center Press, 2006, p. 5, p. 219; more balanced, but Ranković was still seen as Serbian paramount leader in: Tim Judah, The Serbs: History, Myth and the Destruction of Yugoslavia, New Haven: Yale University Press, 2009, pp. 143145; John Lampe and Stevan K. Pavlowitch has more reserved approach concerning accusations toward Ranković, but does not bring any proofs or elaborate deeper reasons in: John Lampe, Yugoslavia as History: Twice There Was a Country, Cambridge: Cambridge University Press, 1996, pp. 279, 284-285; Stevan Pavlowitch, Serbia: The History of an Idea, New York: New York University Press, 2002, p. 172 
deeper causes were the rising cleavages, on the level of a system, among republics and particularly between republics and the federal centre. Struggle for division of power was at the very root of the conflict within Yugoslavia. The Sixth Congress of LCY in 1952 opened the possibility for decentralisation ${ }^{8}$ It was an opportunity for republican leaderships to increase their powers at federal expense. In order to better understand how these changes caused the rivalry within Yugoslavia we will take into account the positions of the people who were holding high posts in the LCY, its republican clones and the republic they were able to influence the events on how the Yugoslav Party and the state will develop.

The period of development that we will focus on refers to the period from the mid of 50s until the Brioni Plenum in 1966. This period was marked by party leadership in search of a path in the new world order during the Cold War, after relations with USSR had been normalized. The stability of the system was an imperative if Yugoslavia wanted to keep its hardly acquired sovereignty. Being a small and undeveloped country meant that political unity was one of its greatest goals. After introducing self-management in 1952, the LCY leadership was again at the turning point in 1958. The major question that was posed among top Party members was whether to continue with more decentralisation ${ }^{9}$ or to return to the course of strong central government decisionmaking. Two main currents emerged: representatives of the idea that self-management is what distinguishes and makes the Yugoslav model superior to the Soviet model and those who thought that the process of decentralization went too far. ${ }^{10}$

We claim that there were at least three reasons behind the Rankovićs downfall. The first was his failure to accomplish the task given to him in 1958 by Josip Broz. This task consisted of restoring unity and much needed party discipline within the LCY. By unity we mean unity in decision-making of the Executive Council of LCY and implementation of that reached decision. Tito as it will be presented latter was the major promoter of that path, which was in fact Lenin's democratic centralism. The second reason was that Aleksandar Ranković and Edvard Kardelj ${ }^{11}$ were, after Broz the two most influential politicians. Even if they were not personally striving to

8 Branko Petranović, Istorija Jugoslavije, pp. 334-335.

9 About federalism in Yugoslavia see in: Sabrina P. Ramet, Nationalism and Federalism in Yugoslavia: 1962-1991, Bloomington IN: Indiana University Press, 1992; Olivera Milosavljević, „Centralizam i republikanizam - nacionalizam u Jugoslaviji 1945 - 1955“, Sociologija, Vol. XXXIV, No. 3, Beograd, July-September 1992; Milivoj Bešlin, „Josip Broz Tito i jugoslovenski federalizam (1963-1974)“, Olga Manojlović (ur.) Tito - viđenja i tumačenja, Beograd: Institut za noviju istoriju Srbije, 2011, str. 58-85; Mile Bjelajac, "Karakter jugoslovenskog centralizma u svetlu analize tajne sednice Izvršnog komiteta Centralnog komiteta Saveza komunista Jugoslavije marta 1962”, Dijalog povjesničara-istoričara, (eds H. Fleck, I. Graovac), Zagreb, 2001, str. 373-393.

10 See more in: Mile Bjelajac, "Karakter jugoslovenskog centralizma u svetlu analize tajne sednice Izvršnog komiteta Centralnog komiteta Saveza komunista Jugoslavije marta 1962", Dijalog povjesničara-istoričara, (eds H. Fleck, I. Graovac), Zagreb, 2003, str. 373-393.

11 Edvard Kardelj, was born in 1910, Ljubljana, Slovenia. He finished the Teacher's Training Faculty, but got involved in illegal political activity, since he joined YCLY in 1926. He was arrested in 1930 and served two years in prison after which he become the head of Slovenian Communist Party. He taught in Moscow at the Communist University for Western minorities. He was a member of Central Committee 1937-1979, within the closest Tito's circle during the WWII, prime minister of Yugoslavia 1946-1953, Minister of Foreign Affairs 1948-1953, Vice President of the government 1953-1963, President of the Federal Assembly 1963-1967. R. Radošin, Jugoslovenski savremenici: Ko je ko u Jugoslaviji, Beograd: Hronometar, 1970, str. 445. 
be Tito's successors, other high members of the LCY had been gravitating towards them. With a crisis evolving and deepening Tito seemed to be a leader who was losing control over subordinates. His age (Tito was 74 in 1966) and health certainly greatly contributed to these rumours. Finally, the economic reforms in 1961 and 1965 did not result in the desired economic growth and stability. The first reform brought instability and recession and the second up to a staggering $30 \%$ price rise. $^{12}$ However, not all parameters were bad, on the contrary, but the effect of both reforms had a heavy impact on the already low standard of living in Yugoslavia.

Tito's trust in Ranković was not unjustified. Ranković was a proven communist. He spent six years in prison before WWII, and he stood firmly when he was arrested in the summer of 1941. During the war he was within the closest Tito's circle. After Tito-Stalin split in 1948 Ranković was again loyal and greatly contributed to stopping any possible dissent within CPY/LCY. Together with Jeftimije Šašić, ${ }^{13}$ Ranković was the iron fist of the new government. With the new constitution in 1953 his power within the state significantly increased. He was transferred from the post of Federal Minister of Interior to a newly created post of the president of Coordination Committee of Interior. With this new post Ranković had control over the federal and republican security services. Combining this high state post with the post of Organisational Secretary within the LCY and his friendship with people like Svetsilav Stefanović ${ }^{14}$ who was his successor to the post of Federal Minister of Interior and Jeftimije Šašić as the head of Security Organs within the State Secretariat of National Defence (DSNO) - there was no doubt that Tito highly regarded Rankovićs loyalty and competence. Having in mind that all this took place at the time when the Soviet Union and its satellites were massing their military effectives along the Yugoslav borders, we can say that Josip Broz among all of his associates, in those days, relied mostly on Aleksandar Ranković.

It is of great importance to say that both Tito and Ranković never had ambitions to be involved in theoretical work or had intentions to contribute to Marxist theory. Both came from poor families, and had no higher education. Both were workers, who had been jailed for their activities. However, Ranković was 17 years younger and as most of the other high ranking communist members he regarded Tito as their father called him Stari - (the old man) In other words, they generally shared certain experiences in life (although Tito's life experience is unique). Both shared a vision of Yugoslavia with a strong federal government and thus it was not strange that after turbulences in the 50s and emerging economic and political crisis at the end of that decade Tito chose Ranković as the person who

12 Fred Singleton, Bernard Carter, The Economy of Yugoslavia, London: Croom Helm, 1982, p. 137.

13 Šašić was born in 1917 in Novka, Croatia then a part of the Austro-Hungarian Empire. He joined CPY in 1939. After the war he was head of military intelligence and security apparatus and head of political bureau for Yugoslav People's Army. R. Radošin, op. cit., p. 1019.

14 Stefanović was born in 1910 in Kučevo, Serbia. He was member of YCLY since 1927 and member of CPY since 1928. He was arrested several times in Kingdom of Yugoslavia. Since the formation of OZN in 1944 he was deputy of Aleksandar Ranković, later he was in 1946 deputy of Minister of Interior during Ranković's ministership. In 1953 he assumed position of Federal Secretary of Interior (position of minister was in 1953 changed with position of secretary). He held the post until 1963. He was member of Federal Government till 1966. R. Radošin, op. cit., p. 983. 
would bring unity to the Executive Committee of LCY and suppress strong and constant pressures of the republican leaders on the federal government. ${ }^{15}$

\section{Overview of the international position of Yugoslavia 1948-1966}

Yugoslavia did not have a strong ideological partner after 1948, but succeeded in resisting the pressure of USSR. Stalin's death (1953) opened possibilities to end hostilities, which was grasped by both sides. The USSR was interested in closing the rift within the international workers' movement by again incorporating Yugoslavia into the Eastern Block. Yugoslavia, on the other hand was exhausted from the blockade and it desperately needed normalization of relations. The declaration that was signed in Belgrade in May 1955 ended hostilities on the state level. Next year in Moscow another declaration ended disputes between the LCY and the CPSU. ${ }^{16}$ Still Yugoslavia remained outside the Eastern Block (EB) but with a desire to revive economic relations with the EB since its economy was projected on the same pattern, despite the changes after 1950. Yugoslavia, not counting Greece and Italy, was surrounded by the Soviet sphere of influence from which it escaped. Without hard currency and with low quality products, low production output, kliring (clearing) system of payment, the huge and less demanding COMECON market seemed to be the best place for the placement of Yugoslav products which would spur the development of Yugoslav industry.

However, American influence was still strong in Yugoslavia in 1950s. Generally the process of de-Stalinization started in the EB in 1956. Abandoning the practices that one person holds the highest posts both in the party and the state Khrushchev seemed as man who would, at the end, accept the special position of Yugoslavia in the world. Still, the head of the CPSU retained the dominant position of the Party. The New Program of LCY presented at VII Congress in 1958 created new tensions with the USSR (1958-1963). ${ }^{17}$ The formation of the European Economic Community (EEC) and mutual economic integration between member states left Yugoslavia economically isolated between two economic blocks. ${ }^{18}$

\section{Internal development of Yugoslavia and rising tensions between the federal centre and republics 1950-1966}

The Tito-Stalin split, after the first shock, posed a dilemma about how Yugoslavia should retaliate in the ideological sphere where it was relentlessly attacked by USSR and its allies. During the "shock period" the CPY leadership

15 Executive Council meetings in 6. February 1958, 14-16 March 1962 and 12-13 November 1965 are the best examples of crisis and disunity within top LCY officials. AY, F. 507, EC CC LCY, III/75; AY, F. 507, EC CC LCY, III/88; AY, F. 507, EC CC LCY, III/113.

16 Branko Petranović, op. cit., p. 357.

17 Dragan Bogetić, "Jugoslovensko-sovjetski odnosi početkom 60-ih godina: razlika u Titovom i Hruščovljevom poimanju načela miroljubive koegzistencije”, Istorija XX veka, 3/2011, Beograd: Institut za savremenu istoriju, pp. 205-206, 210. 
defended itself, ${ }^{19}$ but it adopted a new position as a communist party in 1949 , whose system was closer to the ideal of Marxism-Leninism then that of the CPSU. That approach corresponded with the desires of the West which wanted to see Yugoslavia as more democratic and different from USSR and its allies. In order to understand the extent of the Yugoslav transformation after the Tito-Stalin split, we must mention that at VI Party Congress in 1952, the Communist Party of Yugoslavia (CPY) was renamed into the League of Communists of Yugoslavia (LCY) which underscored that the LCY consisted of parties which corresponded to the federal system of Yugoslavia, where each republic had its own communist party. Self-management was introduced and the ruling role of the LCY was transformed into the leading role in the state and society. The highest party forum - the Party Congress was the body which initiated and defined all these changes, thus the ideas of decentralization were promoted in every sphere of the political, economic and social life. Consequently, the authority of the republics increased on account of the federation, both at Party and state levels. As in the USSR nobody thought that anyone would abuse this opportunity since it was a communist government and not the Kingdom of Yugoslavia. However, in practice the Yugoslav federal republics used the opportunity of newly created relations to take their share of federal power. Tito understood this problem and was aware of the pressure which the republics exerted on the federation. He called the republics "advocates" of various local interests at the expense of the federal government. ${ }^{20}$ At the same time, the republican local leaderships began replicating the centralistic system of federation in their home republics, the very system which they constantly criticized.

Despite its rigidity and monolithic appearance when observed from the outside, the political life in Yugoslavia and in other communist party countries was less dynamic than in the democratic regimes, but it was far from inactive. The official policy, within the system of communist parties, was a product of struggle waged through different party forums around the most powerful officials and with the supreme leader as the arbiter. Executive Committee meetings, plenary sessions and Congresses and other lesser party forums were all previously arranged. Decisions were made in advance on which official(s) would deliver the report(s) that would define the future party policy. Opening and closing words were reserved for those who were the most influential and who laid down the guidelines. Other officials who already had enough experience followed the guidelines of the main report(s) or if not they would become a case for discussion at the next party meeting which will result, at least, in their disposition from all posts. One person, no matter how influential, needed the support of the majority of party members. That support was always secured through the rise in hierarchy and cultivating clientelism in the process. The system relied on a perpetual accumulation of power, which meant that the oldest members usually, but not always, were the most powerful. Having all this in mind, Edvard Kardelj and Aleksandar Ranković were the closest and most influential associates of Josip Broz. Naturally, other, higher and lower party officials gravitated towards one or the other because of their affiliations, beliefs,

19 Josip Broz Tito, $V$ Congress of CPY - Political report at the CC CPY, Belgrade, pp. 111-119.

20 AY, "Executive Committee CC LCY", f. 507, III/75, p. 13. 
interests, etc. Tito's policy of putting someone in charge of a particular problem ${ }^{21}$ and then himself deciding on its final form and character at the very end, even more emphasized this practice in the LCY.

In order to prevent further discord within the LCY and to close the "rift" one of his closest associates needed to be politically neutralised in order to end the division with dangerous potentials within the LCY. Unable to eliminate Kardelj, because of the strong resistance of Slovenia's top party cadres, ${ }^{22}$ he turned on Ranković whose policy of recentralisation alienated him from the home base in the republic of his birth. Binding his source of power only to the federal level and to Tito's mercy, left him exposed when Tito changed his strategy due to his inability to remove Edvard Kardelj. This shows how much trust Ranković had in Josip Broz.

After 1958, Tito supported Ranković because they shared belief that only centralism and old discipline and faith in Party decisions can lead Yugoslavia to peace and prosperity. Those old/new hallmarks probably caused fear among other party members that were in rank below the first two. Unlike the USSR Yugoslavia did not have one powerful republic or nation to overpower the other, which made it impossible to easily destroy the achievements of the empowered republican leaderships. Encountering strong resistance Tito tried with even greater centralistic measures to close the rift in the Party and to regain monolithic appearance.

The economic reform launched in 1961, caused by an economic crisis of balance of payment at the end of 1950s failed, plunging Yugoslavia into a severe recession. ${ }^{23}$ Only by huge government intervention and increased public spending was it stopped in the second half of 1962, but not before it resulted in increased public debt.

Tito tried once more to resolve the problem of disunity by calling a secret Executive Council meeting on 14 Mach 1962. After three consecutive days, the problem was not solved, in fact the dispute escalated and Kardelj with Bakarić's backing continued to oppose even more. If memoir sources were to be trusted, Tito asked Ranković to call a plenary session in order to discuss the position of Edvard Kardelj which Ranković refused, explaining that it would bring more instability, since Kardelj had firm support in the Slovenian federal party and state unit. $^{24}$ In any case Kardelj went to the U.K. for the second time and sickness was used as excuse. ${ }^{25}$

21 Interview with Kiro Gligorov 2010, by Mijat Lakićević, whom I owe this information and sound record.

22 It was a result of three day Executive Council meeting in 14-16 March 1962 when Tito for the last time supported Ranković during a confrontation with Kardelj and others who were for more decentralization on all levels. Kardelj went to UK, under the pretext of illness and Slovenian top official led by Miha Marinko, Kardelj's closest associate in Slovenia stood firmly behind Kardelj, thus putting the pressure on Tito to back down. Dennison Russinow, The Yugoslav Experiment 1948-1974, London: C. Hurst and Company, 1977, p. 107.

23 Dennison Russinow, The Yugoslav Experiment, p. 111.

24 Добрица Ћосић, Пишчеви записи 1958-1968, Београд: Филип Вишњић, 2001, стр. 217.

25 Same situation was when after Tito's visit to Moscow in 1956 Ranković also needed to cool down Tito in his desire to remove Kardelj. Александар Ранковић, Дневничке забелешке, Београд: Југословенска књига, 2002, стр. 126. 


\section{"Rankpovićs concept" of recentralization}

Being given the task of restoring unity within the LCY, Rankovic needed some sort of a plan, concept or platform. Today's available sources are very scarce on this issue. However by analysing the sources that we have at our disposal we can conclude that Ranković had Tito's full support in the period between early 1958 and mid 1962. During this period of a little more than four years, he was guided by the thought, as he said at the February session in 1958, that the source of the problem was not disorganization but demobilization in the Party, including the highest echelon of party members. ${ }^{26}$ This, according to Ranković, resulted in the lack of a united standpoint during decision-making process. ${ }^{27}$ The solution was logical, it was imperative to restore party discipline ${ }^{28}$ Tito strongly supported Ranković at this very meeting. ${ }^{29}$ The reason was that both shared the same vision regarding the position of the LCY in Yugoslavia. The meeting was called because of a large strike of miners that took place in Slovenia early in 1958. The problem becomes a major issue since Tito accused the Slovenian leadership as the instigators of crisis. Tito directly named Miha Marinko, the leader of League of Communists of Slovenia. ${ }^{30} \mathrm{He}$ accused them of using social discontent in order to exert pressure on the federal government ${ }^{31}$ to get permission to export raw materials to Austria where they could get several times over a better price than if they sold it within Yugoslavia as planned. Tito saw this case as the last drop that spilled the cup. It marked the turning point in the relations between the federation and the republics. Further reading of Tito's speech reveals the magnitude of the conflicts between the republics and federal organs. Croatia and Bosnia and Herzegovina were named as places where these transgressions occurred. Federal inspections were expelled in Croatia or severely beaten in Bosnia and Herzegovina. ${ }^{32}$ Despite Tito's interventions, certain directors of enterprises were not dismissed from their posts although they bullied the workers but were protected by high republican officials. ${ }^{33}$ This was a direct obstruction of Tito's authority. With the support of high republican officials, directors were able to nullify Tito's actions. ${ }^{34}$ Broz claimed that although the Party was given the leading role in

26 Meeting of Executive Committee of CC LCY in 19. July 1962. AY, "Executive Committee CC LCY”, f. 507, III/75, p. 26

27 AY, "Executive Committee CC LCY", f. 507, III/75, p. 26.

28 AY, "Executive Committee CC LCY", f. 507, III/75, p. 31.

29 AY, "Executive Committee CC LCY”, f. 507, III/75, p. 32

30 Distributions of equipment and differences in salaries were in fact major trigger for the strike of miners in Trbovlje and Zagorje coal mines. Miha Marinko who was born in Trbovlje distributed new equipment to new mines in Velenje, Slovenia. Slovenian leadership was accused for not reacting earlier and preventing social discontent, submitting to the workers' demands. AY, "Executive Committee CC LCY", f. 507, III/75, p. 8. This created a precedent because it was used as an opportunity to ease the authority of planned economy regulations on the economy in their republic.

31 Belgrade was constantly, as in this case, accused for "Serbian centralism and hegemony". Tito immediately realised that this struggle between republics and federation was more significant than the ordinary sporadic quarrels, and that it challenged the system itself. AY, "Executive Committee CC LCY", f. 507, III/75, p. 6.

32 AY, "Executive Committee CC LCY", f. 507, III/75, p. 13.

33 AY, "Executive Committee CC LCY", f. 507, III/75, pp. 10-11.

34 AY, "Executive Committee CC LCY", f. 507, III/75, p. 10. 
1952, it should remain as the ruling Party (without changing the phrase: leading) ${ }^{35}$ If Tito wanted to successfully manoeuvre between blocks he needed a strong and united Party. He could not allow disobedience or rift to happen within the LCY. At the February meeting 1958 Tito had addressed the other members of Politburo and raised the question of Party unity. On that occasion, he directly told Aleksandar Ranković that some party members had wrongly understood the position and the role of the Party and started to assert certain deviations. ${ }^{36}$ The meeting exposed that, according to Tito's stance, republican disobedience and criticism towards the federation had reached a climax. This meeting was also of great importance because Aleksandar Ranković delivered the closing report in which he explained what the causes of this behaviour were and what according to him the solution was.

Tito started to perceive decentralization as disunity of action; therefore he gave his most trusted collaborator the task to reinstate "unity". In the process of reinstating "unity" inside the LCY other high ranking party members would be deprived of their positions. If we are right, than Tito thought that he could not allow disunity to evolve in a period of economic crisis and while Yugoslavia was faced with the Cold War, so he ordered his Organisation Secretary of the LCY and President of the Federal Committee of Interior to deal with the issue. On the other hand, the reformists were party officials who wanted to retain their positions and privileges. Those who were against the new wave of recentralization thought that they had three good arguments in their favour. The first was Yugoslavia's national complexity, the second socialist self-management that was an important factor because it was the main Yugoslav ideological identity among socialist countries and workers movement. The last one was that, although troubled by disunity, Yugoslavia still represented an over centralized system. Despite the processes in 1950s, Yugoslavia was a very centralized state and its economy was being stifled by such a state. Thus, the reformists thought that the intended task that Tito and Rankovic wanted to undertake was too simple and totally wrong, since centralization was the cause not the solution to the problems. Comparing "glorious old days" of unity in the revolution to peace time and need to modernize a backward country that intended to be a supreme model of modernization for developing nations was absurd.

One of the options discussed at the meeting held in February 1958 was the possibility of purges in the LCY, since the other option was, as Tito said, for the Party and state to disintegrate. ${ }^{37}$ The words had great weight since exactly 10 years earlier Ranković and Jeftimije Šašić took the same stance within repressive apparatus. Other participants were probably caught by surprise, even Vladimir Bakarić $^{38}$ devotedly announced to take harsh measures against anyone in Croatia who opposed the will of the General Secretary of LCY. The logic of his thinking was that just faith in the Party, discipline and responsibility would make the

35 AY, "Executive Committee CC LCY", f. 507, III/75, p. 10.

36 AY, "Executive Committee CC LCY", f. 507, III/75, p. 10.

37 AY, "Executive Committee CC LCY", f. 507, III/75, p. 6.

38 Vladimir Bakarić was born in 1912 in Gorica near Zagreb. He graduated from the Faculty of Law and did a PhD in 1937 in Zagreb. He became member of the CPY in 1933. He was active in Partisan movement as one of main organisers of Partisan resistance against Independent State of Croatia in WWII. From 1944-1969 he was head of Croatian Communist Party branch and thus the first man in Croatia. R. Radošin, op. cit., 1970, p. 47. 
socialist revolution possible. Hence, the LCY should return to those values. The crucial problem was in the lack of centralism. After closely analysing every speech, it seems that only Tito and Ranković were prepared for what would be said at the meeting. Jovan Veselinov, the general secretary of League of Communists of Serbia spoke after Broz emphasizing the importance of unity in decision making. ${ }^{39}$ Only Kardelj was reserved but nothing more, everybody just agreed, supporting Tito in their speeches.

One of the first measures was to stop convening the Executive Council meetings. From the VII Congress of the LCY in Ljubljana held 22-26 April 1958 until May 1959 no Executive Council meetings were held for more than a year. ${ }^{40}$ During that time, Tito had ruled Yugoslavia with the help of Aleksandar Ranković and Ivan Gošnjak, Federal Secretary of Peoples Defence. This form of running the Party without consulting other major political leaders was no solution to the problem.

If we look closely into the folder of Commission for Development of Cadres, ${ }^{41}$ we will be surprised with its activity from 1959-1964. However, it is surprising that after the first huge increase in data by 1964 its activity started to slow down and in 1965 the Commission was barely functioning. ${ }^{42}$ The questions it was addressing in 1965 begun to be too abstract and general. From 1959-1963, even a bit during 1964 the Commission dealt with creating huge data bases and discussed how many functions each member of LCY had. Some of them had circa 15 or more and it was necessary to relieve them of some duties so they could focus on their work and at the same time make room for younger cadres. ${ }^{43}$ For example, if we look the year 1962, we can see that a new register had been made. This was prepared for the new LCY Congress that would determine Party policy for next 4-5 years. This was an opportunity for Tito and Ranković to install the cadres according to their wishes.

It is interesting that in the same year we have lists of nomenclature members who had a villa in their possession. How much the value of each villa was, how much was invested in it and what the value of the villa was in 1962. Of great importance is the origin of invested money in each villa. ${ }^{44}$ All of this was presented at the Executive Council meeting as non-communist behaviour.

Throughout that period, especially 1959-1963 the Party was working to reduce the functions of officials who had accumulated too many duties and were thus unable to carry out all of them effectively. Some of them had more than 10, 15 or 20 functions. ${ }^{45}$ This task could not have been executed without Aleksandar Ranković, since he was Org-secretary. His duty was also to determine who the old

39 AY, "Executive Committee CC LCY", f. 507, III/75, pp. 16-22.

40 Dennison Russinow, The Yugoslav Experiment, p. 107.

41 AY, f. 507, A-CC LCY, Commission for Development of Cadres, XIII, k. 7-9.

42 AY, f. 507, A-CC LCY, Commission for Development of Cadres, XIII, k.10.

43 Meeting from 6. June 1958. AY, f. 507, A-CC LCY, Commission for Development of Cadres, XIII, k. 6/9, p. 4; Meeting from 1. July 1960, ibid. 7/9, p. 3.

44 Meeting of Executive Committee of LCY in 19. July 1962. AY, "Executive Committee CC LCY”, f. 507, III/92, attachment 3.

45 Meetings of the Commission and extra materials from 1959-1963. AY, "Commission for Development of LCY and Cadre Policy", F. 507, XIII, k.7/9, p. 2. 
officials were and to give the chance to new, younger party members. ${ }^{46}$ No doubt that this policy angered many high LCY officials.

Increased activity of the Commission for Development of Cadres, ${ }^{47}$ huge campaign of collecting and sorting new data for every member of LCY, dismissing LCY members from certain posts and listing their weekend houses possessions ${ }^{48}$ in great details certainly was not welcomed by the LCY members. It seemed as if they had been under investigation, and that they had started to behave as a new, untouchable elite with very distantly connected with ordinary citizens. From the point of view of Org-secretary this was done in order to create a fresh data base that would improve the Commission's efficiency. However, all these activities could have seemed ominous to the LCY members, especially if we have in mind the turbulences in the Executive Committee from 1958 and 1962 and Tito's speech in Split, Croatia in May 1962, which was in fact his summary of the March meeting. In April 1962, Ranković tied to be more aggressive towards the Slovenian leadership when he said at Executive Committee meeting at $3^{\text {rd }}$ of April: Only conclusions of Slovenian Executive Committee CC SK Slovenia deviate from the conclusions of EC $C C L C Y$. They are in contrast to the whole extended meeting. It gives the impression of silent disagreement. That would be the worst form of relations within our Party. These things should be discussed, otherwise there are no guarantees that our findings will be correctly accepted and implemented. That impression does not lie just within these findings, but it has roots in different conceptions, which were revealed in its full form at the January (1962) meeting of CC SKSlovenia. ${ }^{49}$ Despite Ranković's stance there were no consequences for any member of Slovenian leadership.

\section{Aleksandar Ranković - decline and fall from power}

But then the change did happen. Kardelj was appointed the President of the Constitutional Commission, whose task was to draw up the new (1963), third, more federal constitution and rename the country the Socialist Federal Republic of Yugoslavia.

Obviously, it was Ranković's inability to solve the problems dealing with more centralism, and the firm backing of the Slovenian federal unit to Kardelj that forced Tito to reconsider his judgment. However, between the two groups: Tito and Ranković on one side and that of Kardelj and Bakarić on the other, there was a third group of high ranking officials of the LCY who saw the opportunity in selfmanagement and in the decentralization process to reform the Yugoslav economy and state. We can position them into the reluctant group. They did not support the crude centralistic system and advocated for more market instruments in the economy. Serbian cadres together with the Croatian and Slovenians represented

46 AY, "Executive Committee CC LCY", f. 507, III.

47 Meetings of the Commission and extra materials from 1959-1963. AY, "Commission for Development of LCY and Cadre Policy", F. 507, XIII, k. 7-9.

48 Meeting of Executive Committee of LCY in 19. July 1962. AY, "Executive Committee CC LCY”, f. 507, III/92, pp. 6-7; especially attachment 3 from the same meeting where all nomenclature members have been listed, together with their seaside villa. 
the majority of the LCY cadres. These cadres and the unsuccessful policy of recentralization and enforcing discipline in LCY were the forces that would end Ranković's career.

Ranković had blind faith in Tito because he had been chosen to solve the problem of unity in the LCY and was appointed the vice president, thus he was feeling overconfident. His other mistake was an inability to realize that the process of decentralization of such a rigid system was inevitable, when Yugoslavia started to open towards the West in 1950s, otherwise the Yugoslav economy would collapse. Of course a harsh and quick decentralization was unsuccessful mostly because it had been implemented in a centralistic manner. Further, Ranković underestimated the potential of republican political organizations. Being from Serbia he could count on the support of the largest federation unit, however that was in collision with his task. If we examine the meetings of the Serbian government we will notice that not even one economic problem that troubled Serbian authorities was passed on to Ranković to help with its solving. Serbian republican cadres counted on Mijalko Todorovićs ${ }^{50}$ (in charge of economic affairs) and Petar Stambolić (prime minister of Yugoslavia 1963-1967). If the rumours were correct about conflict between Ranković and Slobodan Penezić Krcun ${ }^{51}$ than we can conclude that Ranković not only lacked support from the Serbian political unit but faced a steady growing opposition of Serbian cadres on both the federal and republic level.

In 1963, he was appointed vice president and with his power as Orgsecretary of LCY it seemed as if his power was increasing, however he no longer held the post of the President of Federal Board of Interior and the LCY which now had its republican branches and were more powerful than ever, which consequently limited Ranković party powers in the republics.

Taking in consideration the previously given situation, we can conclude that somewhere at the end of 1963 when he was appointed the vice president, according to the new Constitution, because of his mistakes, he stood almost alone in the political arena and after more than five years the problems were unresolved, only the economic situation in Yugoslavia was worse.

50 Todorović Mijalko was born in 1913 in Dragušica, near the town of Kragujevac in Serbia. Before the WWII he finished Technical Faculty (section for Mechanical Engineering) in Belgrade. He became member of the CPY in 1938 He actively participated in the resistance during WWII as deputy of political commissar of the First Proletarian Division (the first division established by CPY during WWII), later he was promoted to the first commissar of the First Army). He was Minister of Agriculture and President of Council for Agriculture and Forestry till 1953. He was member and vice-president of Federal Executive Council (Government) from 1953-1963, president of Federal Assembly 1963-1966. R. Radošin, op. cit., pp. 1078-1079. He was also the key person in Yugoslavia for economic issues from 1958 till 1963 he was President of Economic Council of Federal Executive Council. This institution was like a super ministry, monitoring and running secretariats of economy, finance and agriculture.

51 Slobodan Penezić was born 1918 in Užice, Serbia. Student of agronomy in Belgrade. He was political commissar of the Second Proletarian Division during WWII. He was Minister of Interior in republic of Serbia 1946-1953, later member and then vice president of Serbian Executive Council (Serbian government). He was also member of Federal Executive Council. Slavko Jovanović, Mihajlo Milanović (ed.), Ko je ko u Jugoslaviji: biografski podaci o jugoslovenskim savremenicima, Beograd: Sedma sila, 1957, p. 531. From 1963 till his death in a car accident in November 1964 he was President of Executive Council of Serbia. 
Now Tito's burden was heavier than ever. The policy which he ordered Ranković to carry out proved to be a total failure. Since the LCY derived its power from the revolutionary struggle and ideological supremacy, the possibility that something could go wrong was never an option. The system was forcing other cadres to seek help from Kardelj or Ranković in order to protect their interests. Ranković, unlike Kardelj was deaf for the appeals coming from his republic. With no solution in close sight, Tito appeared more as a spectator in internal policy, which in the long run could undermine his own authority. His age and health were not on his advantage. In order to retain his influence and impose his will in the Party he needed to prove that he was still capable of risky but radical moves. One side needed to go and Ranković was the one who had no support from his republic.

However, the removal of Ranković from his posts needed to be presented as a logical continuity of Party development. Since Ranković was not involved with party ideology, it was necessary to find different reasons for his downfall. Tito faced one more problem concerning Rankovićs removal from power and it was Ranković's standing in the LCY and state. He had tremendous authority within the LCY and thus had the nickname "the soul of the Party". ${ }^{2}$ So, it is no surprise that Tito choose him, at first, to carry out the "unification mission". Thus, the accusation against him needed to be brutal, shocking and shameless, convincing at first hand. After gradually limiting his state and party powers, the same process was undertaken with his close associates. Svetislav Stefanović Ćeća, Federal Secretary of Interior, was the first to be removed from his post and transferred to Federal Assembly, Jeftimije Šašić followed. The final change was the shift of Vojkan Lukić, Federal Secretary of Interior after Stefanović who was transferred to LCSerbia as Org-secretary late in 1965. This transfer of Lukić occurred thanks to General Secretary of LCSerbia Dobrivoje Radosavljević who quickly joined the winning team, since he always supported the implementation of market instruments and decentralization in economy. Jovo Kapičić, ex-member of security apparatus gave Tito the cadre structure of State Security Service and prediction of their reactions if Ranković was attacked. ${ }^{53}$ Ivan Krajačić Stevo ${ }^{54}$ helped in sending Croatian operatives from their republican security service ${ }^{55}$ to check Josip Broz's mansion. They discovered the microphones, but it was unusual that they were without power source and unable to transmit information.

52 Group of authors, Snaga lične odgovornosti, Belgrade: Helsinki Committee for Human Rights in Serbia, 2008, p. 82

53 Tamara Nikčević, Goli otoci Jova Kapičića, Podgorica: Daily Press, 2009, p. 219.

54 Ivan Krajačić Stevo was born in 1906 in Poljane near Nova Gradiškap Croatia. He became member of the CPY in 1933. He fought in the Spanish Civil War 1936-1938 and had a rank of Capitan of Republican Army. During WWII he was one of the main leaders of Partisan resistance in Independent State of Croatia. He was org-secretary of Central Committee of Communist Party of Croatia. After the war he was Minister of Interior in Croatia 1946-1953, vice-president of Croatian Assembly 1953-1963 and President of Croatian Assembly 1963-1967. He submitted his resignation to League of Communists of Croatia. R. Radošin, op. cit., pp. 508-509. 
Both crucial posts in the civil and military security apparatus had been replaced by Croatian cadres the Mišković brothers Ivan ${ }^{56}$ and Milan. ${ }^{57}$ Tito had full state support thanks to Petar Stambolić. At the Party level after the VIII Congress republican organizations gained more power diminishing federal structure where Ranković was second strong man. However, he still had power in the Party, thus the preparations for his removal were carried out through state structures.

One of the key events was the extended LCY meeting of Executive Council on 12th and 13th November 1965. If we compare this meeting with the one of February 1958 we can see that the roles had changed. This time Kardelj had the final word, but unlike Ranković's final word in 1958 where the main problem was a demobilized Party, Kardelj said:

But there are those who think that it is necessary to create order and force using the policy of firm hand in Yugoslavia. And when I say the firm hand I say it with negative connotation, to force upon, in fact, one greater system which will subdue to that greater interest all the other just interests of all nations in Yugoslavia. ${ }^{58}$

Although camouflaged in syllogism, it was clear who had the upper hand. Ranković was unaware of the scale of the future events. The final showdown came in June $16^{\text {th }} 1966$ at a secret extensive LCY Executive Committee meeting. He was accused for spying on Tito and putting microphones in his bedroom and bathroom in his Belgrade mansion and that conspiring to overtake the LCY with secret police SDB. Ranković was stunned but quickly regained his spirit, understanding that he was caught within Party machinery like many before him. He cooperatively offered his resignation from all posts, which was accepted. Political Commission had been set up to interrogate him for the second time on $22^{\text {nd }}$ June, before the plenary session. ${ }^{59}$ It was said that Technical Commission would also be formed and it would examine the evidence. However, its report was never published. Fourth plenary session was held on the island of Brioni, Croatia and just several participants knew what was happening.

The operation was brilliantly planned in Tito's closest circle. ${ }^{60}$ It was decided who would give speeches, what would be said and in what order. Tito personally spoke with every important official, especially with the Serbian cadres. The deposition of Aleksandar Ranković opened the question who would replace him at the posts which he held. Serbian cadres were aware of the importance of these posts and the power that they would lose if they were taken by someone else. That is why one of the conditions of Serbian support was that Konstatin

56 Ivan Mišković was born in 1920 in Premantura, near Pula, Croatia. Ex-law student, after the WWII he finished Higher Military Academy. He became member of CPY in March 1941. He actively fought in WWII He was in high position in military intelligence after the war and he replaced Jeftimije Šašić in 1963 as the head of Security Organs in State Secretariat of National Defence (Defence Ministry). R. Radošin, op. cit., p. 678.

57 Ilan Mišković was born in 1918 in Premantura, near Pula, Croatia. He was a student of Faculty of Engineering in Zagreb. He became member of CPY in 1940. He was active during WWII. After the war he was in OZN till 1946, later he was State Secretary of Interior in Croatia 1953-1963 and Federal State Secretary of Interior in 1965-1967. R. Radošin, op. cit., p. 679.

58 Executive Committee meetings, 12-13 November 1965. AY, “EC CC LCY”, F. 507, III/ 113, p. 164.

59 AY, “LCY”, F. 507, IV (Brioni) Plenum 1966, VII 1, II/28, attachment 1, p. 6.

60 Predrag Lalević, S Titom po svetu, Beograd: Službeni glasnik, 2011. 
Popović, ${ }^{61}$ Mijalko Todorović, Milentije Popović ${ }^{62}$ and Dobrivoje Radosavljevićc ${ }^{63}$ assume ex Ranković's posts or be promoted. ${ }^{64}$ They gave Broz full support in exchange for a discussion on the army and party reform, which Tito agreed to do. ${ }^{65}$ What they were unable to compensate was the reputation and authority within the LCY which Aleksandar Ranković had. Among the prominent Serbian cadres, no one was older than Ranković and so close to Josip Broz. In other words, despite retaining the posts within the Serbian ethnical sphere, Serbian influence was diminished. On the other hand, Serbian cadres strongly disagreed with Ranković's ideas, they saw them as unacceptable.

Rankovic received the meeting agenda only on the night before the plenary meeting, and after reading it had a heart attack. ${ }^{66}$ At the plenum Ranković denied all allegations, except the moral one and accepted the possibility that during his long stay in power he probably made mistakes and that his time had run out. Svetislav Stefanovic was also accused at plenum more belligerently but he did the same as Ranković.

All Ranković posts had been transferred to Serbian cadres to soothe possible Serbian discontent. Mijalko Todorović became the organizational secretary, but did not become member of the Executive Committee. He was appointed president of Commission whose task was to reform the LCY. The thesis of that Commission had never been implemented. Tito used it to cool the tense situation. Konstantin Popović, very popular in Serbia and Yugoslavia, became vicepresident but he resigned when he realized that no significant changes would occur and that Ivan Gošnjak, Federal Secretary of People's Defence was ousted from his position.$^{67}$ Although no judiciary measures had been taken against Ranković, Josip Broz generously offered to pardon him by, which he accepted.

61 Konstantin Popović, nickname Koča, was born in 1908 in Belgrade in a rich Serbian family. He graduated philosophy at the Sorbonne, Paris; became member of CPY in 1933; was arrested several times because of his political activities; participated as a volunteer in the Spanish Civil War (1937-1939) and in WWII as a commandant of the first organized Partisan unit-the First Proletarian Brigade. He commanded the Second Yugoslav Army in final operations of WWII. After the war, he was Chief of Staff of Yugoslav People's Army 1945-1953; Foreign Affairs Minister and member of Federal Government from 1953-1965; replaced Aleksandar Ranković as vicepresident of Yugoslavia from 1966-1967. R. Radošin, op. cit., p. 827.

62 Milentije Popović was born in 1913 in Crna Trava, Serbia. He graduated from the Faculty of Engineering in Belgrade; became member of CPY in 1939; participated actively in WWII after which he was Minister of Trade and Supplying and Planning Commission in Serbian government 19451948. Between 1948 and 1953, he was Federal Minister of Trade and Federal Minister of Finance. After the fall of Ranković he took his post in Executive Committee of LCY. R. Radošin, op. cit., p. 828.

63 Dobrivoje Radosavljević Bobi was born in 1915 in Knjaževac, Serbia. He studied agronomy in Belgrade, but never finished it. He became member of LCY in 1933; because of his activities he was arrested and put in jail; was active in Partisan movement during WWII. He was Federal Minister of Finance from1948-1950. After the fall of Ranković, he was co-opted in Central Committee of LCY and appointed president of Central Committee of LCSerbia. R. Radošin, op. cit., p. 867.

64 It is interesting that Bilandžić depicts, correctly, complex motives of Serbian leaders who gave strong support to Tito in removing Ranković and elaborating thoroughly the factors that had influenced the removal of Ranković, but at the same time abiding to the official accusations of Ranković. D. Bilandžić, op. cit., p. 487.

65 Venceslav Glišić, Susreti i razgovori: prilozi za biografiju Petra Stamobolića, Belgrade: Službeni glasnik, 2010, p. 86; М. Пиљак, ор. cit., p. 80.

66 Predrag Lalević, S Titom po svetu, Beograd: Službeni glasnik, 2011.

67 AY, "League of Communists of Yugoslavia”, f. 507, VII 1, II/28, p. 152. 
Josip Broz's final words of at the Brioni plenum were that despite the events it was time for unity and state stability. He also added that those who thought (meaning the West) that liberalism would come after Ranković were wrong. Indeed he was right. Leaders of so called reformist block Kardelj and Bakarić mainly stood aside during the whole process. Probably not to irritate the Serbian ethnical component, but they were certainly happy that Josip Broz, mastermind of the whole event, directed his edge at Rankovic and not at them. The State Security Service (SDB) and some other security agencies were purged because they were thought to be sympathizers of Ranković. ${ }^{68}$ But after everything had settled there were no signs of reforming the military or reform in the LCY. In just five-six years Broz destroyed the last threat to his rule purging the Party throughout the country, especially in Croatia in 1971 and Serbia in 1972.

Practically everything ended in destroying one of the most powerful men within a highly centralised government, instead of transforming the government itself into a more democratic one, as was promised by everyone at that time. ${ }^{69}$

These words said on this event confirm that some of the "reformists," led by Bakarić and Kardelj, and supported by Tito, were above all concerned with losing their posts and their power. Had they wanted to truly reform the system through democratization, their power and influence within the system would have been curbed, which obviously was not their intention.

\section{Conclusion}

Josip Broz Tito was certainly the mastermind in the power game. His charisma, sense for compromise combined with brutality when needed, secured him the position of number one in Yugoslavia. Although closer to Ranković than Kardelj, on the issue of central government, Tito needed to act and not allow to be overrun by events. In removing Ranković he cunningly used decentralists forces and those who were Ranković's rivals in power as instruments in his scheme. He wanted to show that he was in control of the whole process and every other major issue in Yugoslavia. Those who helped Tito in this operation were soon retired like Gošnjak, the Mišković brothers, Krajačić. The others did as they were told, like Kardelj and Bakarić who were silent through the plenary session at Brioni. The crucial importance of the military whose loyalty was obviously unquestionable was evident in the whole operation. The whole Brioni plenum in 1966 also had two important implications: the first being that no one was untouchable who was lower in rank than Tito. Even the most trusted, loyal comrade could fall from power if he was weak and unsuccessful in getting the task done. The second was that only a strong backing he or she had in one of the major republics could protect someone's position. Thus, Tito showed that the

68 Antun Duhaček, Ispovest obaveštajca: uspon i pad jugoslovenske obaveštajne službe, Beograd: Grafopress, p. 76. More details about purges and its origins and consequences could be found in Zdravko Vuković, Od deformacija SDB do maspoka i liberalizma: moji stenografski zapisi 19661972, Beograd: Narodna knjiga, 1989.

Aleksandar Nenadović, Razgovori sa Kočom, Zagreb: Globus, 1989, p. 140. 
power game could be brutal if he sensed that the strife within the LCY went too far and began to undermine his authority. Regaining authority was an imperative for Tito, and Ranković played a part in it, if not as one who could have solved the problem then as a scapegoat.

\section{Резиме}

Милан Пиљак

\section{Игра моћи у Титовој Југославији: загонетка смене Александра Ранковића}

Кључне речи: јединство СКЈ, „пукотина“ у Партији, Александар Ранковић, Брионски пленум 1966.

Брионски пленум 1966. остао је упамћен по смени Александра Ранковића, до тада, како се сматрало, другог човека у Југославији. Оптужбе против њега су деловале шокантно, што је и био циљ, јер је смисао целог процеса био уништење политичког утицаја Ранковића. Досадашња истраживања и документа све чвршће потврђују да је, што се тиче оптужби за које су га теретили, Александар Ранковић био невин. У тежњи да се разумеју прави разлози његове смене извршена је анализа промена у држави и Партији након сукоба Тито-Стаљин, као и концепата најутицајнијих људи и њихових истомишљеника. Рад је показао да је још 1958. Броз сматрао да је Југославија у великој политичкој кризи која је настала због тражења новог пута након 1948. и због привредних тешкоћа у којима се налазила. За решавање проблема јединства унутар врха СКЈ одабрао је Александра Ранковића, са којим се слагао око узрока који су до њега довели. Ранковић није успео ни након четири године да реши проблем јединства СКЈ, а током процеса затварања „пукотине“ унутар врха СКЈ савезну власт је поставио као врховну изнад свих република и тако себи одсекао базу за одмеравање и наметање свог концепта на савезном нивоу. Другим речима, Ранковић не само да је био по убеђењу Југословен већ се сам одрекао подршке српске републике. Сматрамо да је ово чинио из принципијелних разлога уско везаних за концепт који је примењивао током покушаја да заустави слабљење савезне владе, опходећи се према српској републици као према било којој у Југославији. Броз се суочио са неуспехом да поврати јединство у врху СКЈ, са неуспелим привредним реформама, иза којих је стајао целокупан ауторитет СКJ, и све успешнијим отпором струје која се залагала за све већу улогу република у савезном одлучивању. У немогућности да смени децентралисте, док је Ранковић својим федералним концептом одсекао подршку српске републике, Броз је одлучио да се реши најближег сарадника, узимајући га за „жртвеног јарца“ кривог за пропале реформе и 
сматрајући да ће тако окончати даље сукобљавање између централиста и децентралиста. Бивајући све старији и слабијег здравља, Броз је морао да покаже снагу како би ставио до знања да није пуки посматрач сукоба између ове две струје. Сматрамо да је Броз руководио целокупном акцијом, да се дуго ломио, али и постарао да све оне који су на оперативно-обавештајном плану учествовали у операцији смене Ранковића полако и тихо уколони са сцене. Браћа Мишковић, Иван Крајачић Стево и други полако су отишли у пензију, а Владимир Бакарић и Едвард Кардељ, најутицајнији политичари у Хрватској и Словенији, руководили су се смерницама које им је Броз одредио. 